International Journal of Economics, Business and Accounting Research (IJEBAR)

Peer Reviewed - International Journal

Vol-2, Issue-2, 2018 (IJEBAR)

ISSN: 2614-1280, http://www.jurnal.stie-aas/ijebar

\title{
THE EFFECT OF SERVICE LEVEL BAITUL MAAL WAT-TAMWIL TUMANG ON MEMBER'S SATISFACTION OF MUDHARABAH DEPOSITS
}

\author{
Wikan Budi Utami ${ }^{1}$ Suhestiningsi ${ }^{2}$ Paidi $^{2}$ \\ ${ }^{1}$ Tax Management Study Program, STIE-AAS Surakarta, Central Java, Indonesia \\ budiutamiwikan@gmail.com \\ ${ }^{2}$ Accounting study program, STIE-AAS Surakarta, Central Java, Indonesia \\ hesti.hegi@gmail.com \\ ${ }^{3}$ Islamic Economic Study Program, STIE-AAS, Central Java, Indonesia
}

\begin{abstract}
The purpose of this study was to determine the effect of service quality which includes compliance, assurance, reliability, tangible, empathy, and responsiveness to the satisfaction level of deposit members. mudaraba in KSPPS BMT Tumang Selo Branch. This study uses a quantitative descriptive approach with a population of mudharabah savings members in KSPPS BMT Tumang Selo Branch, the sample is taken using simple random sampling method. The data analysis is using multiple linear regression models.

The results of this study indicate that the adjusted $\mathrm{R}$ square determination coefficient is 0.648 . This shows that the independent variable is able to influence the dependent variable by $65 \%$, while the remaining $35 \%$ is obtained by other variables outside this research. Based on the $\mathrm{F}$ test shows that the significance number is 0,000 , this states that the independent variables together can affect the dependent variable. The percentage based on variable empathy t test and responsiveness have a significant positive effect on member satisfaction, while the variables of compliance, assurance, reliability and tangible have no significant effect on member satisfaction.
\end{abstract}

Keywords: $\quad$ Service quality, member satisfaction and mudharabah savings.

\section{Introduction}

Cooperatives are very special business entities, because cooperatives are more concerned about mutual destiny, not just leaders. Savings and Loan Cooperatives and Sharia Financing abbreviated as KSPPS have different dimensions from conventional savings and loan cooperatives as well as compared to BMT.

Savings and Loan Cooperatives and Sharia Financing (KSPPS) and BMT have almost the same management system, the difference being in the institution is that the sharia cooperative only consists of one institution, namely the cooperative run with the sharia system. Whereas in BMT there are 2 (two) institutions which are taken from the name "Baitul Maal Wa At Tamwil" which means Zakat Institutions and Financial Institutions (Sharia).

Savings and Loans Cooperative and Sharia Financing Baitul Mal Wat-tamwil 


\section{Vol-2, Issue-2, 2018 (IJEBAR)}

ISSN: 2614-1280, http://www.jurnal.stie-aas/ijebar

Tumang (KSPPS BMT Tumang), is one of the micro-finance institutions originating from Boyolali district which until now developed to Salatiga regency, Semarang regency, Sukoharjo regency, Magelang regency, Klaten regency and Surakarta regency which always show positive performance from time to time.

The development of services to consumer satisfaction is the main concern of KSPPS BMT Tumang at this time. Consumer satisfaction is at present the main concern of all institutions. The economic system and the order of life that was put forward in the New Order era could not provide answers to the hope of the realization of a just and prosperous society. Service for member satisfaction is very important for the stability and development of Tumang BMT.

The level of member satisfaction can be measured through an assessment of the services provided. One approach that can be used to measure the level of satisfaction of Muslim consumers is through the CARTER approach, namely the measurement model owned by Othman and Owen (2002) in Dani Rohmati and Sunan Fanani (2016), which includes measurement of compliance, assurance, reliabillity, tangible, empathy and responsivenes. These six service factors will be used to measure the level of satisfaction of members of the mudharabah deposit in KSPPS BMT Tumang Selo Branch.

Compliance is the most important dimension in measuring service quality due to sharia compliance which is a manifestation of a Muslim's existence. Compliance is compliance with the rules or laws set by Allah Ta'ala. The ability of financial institution to apply sharia principles in its operations. Does not lend money, but implements a system of profit sharing and trading in transactions.

Assurance is the ability of employees to the knowledge of the product appropriately, quality, hospitality, courtesy in providing services, information skills and ability in instilling consumer confidence in the company. In providing services to members should financial institutions instill a sense of trust and communication so that members still believe in the products contained in the financial institution.

Reliability is the ability to provide promised services accurately, quickly and satisfactorily physically and reliably. This means that the services provided must be reliable, responsible and employees should be polite and friendly. Members will feel satisfied if the service received as expected.

Tangible (physical ability) is a form of physical appearance including supporting infrastructure, facilities, equipment, employees and other means. The physical ability of the company can be seen from the appearance of its employees, waiting room, parking area and so on. Services in tangible dimensions can be seen directly with the eyes directly, so members can directly assess the services provided to them.

Empathy (attention) is the company's ability to give individual or personal attention to consumers. Both companies and employees must be able to establish relationships, good communication, 


\section{Vol-2, Issue-2, 2018 (IJEBAR)}

ISSN: 2614-1280, http://www.jurnal.stie-aas/ijebar

personal attention and understanding of the individual needs of members.

Responsiveness is a response or alertness of employees in helping consumers and providing fast and responsive services. With the alertness given by the employees to its members, the members will feel comfortable and satisfied with the services provided.

The fundamental difference from other models is that the CARTER approach focuses more on the measurement of compliance which means that the ability of the company to fulfill Islamic laws. The purpose of Islamic banks will be appropriate if it is derived from the objectives of sharia (maqasid sharia).

\section{Underlying Theory}

\subsection{Pervious Study}

The research conducted by Kharismarisa Nurhayati, Nyata Nugraha (2015), entitled Analysis of the influence of service quality on the members' satisfaction of KJKS BMT Fastabiq. Based on the research, it was found that among the various service variables given to KJKS BMT Fastabiq Pati members, the compliance variable was the most dominant variable affecting the members' satisfaction of KJKS BMT Fastabiq Pati.

Subsequent research conducted by Dani Rohmati and Sunan Fanani (2016), entitled Implication of service quality on the CARTER approach and its influence on employee's satisfaction in cooperative UJKS. The research was carried out in the employee cooperative of the sharia financial services unit of the Palapa Nusantara Foundation. Service quality variables with indicators of tangible, reliability, responsiveness, assurance, and empathy together have no effect simultaneously on member satisfaction. Whereas the dimensions of reliability and responsiveness have partial effect on the members' satisfaction of cooperative employees of the Islamic Financial Services Palapa Nusantara Foundation. While for the most influential service dimension is reliability.

Another research was also carried out by Zuanita Amalia Sulistiyani (2017), with the title Analysis of service quality on member satisfaction with CARTER dimensions. The study was conducted on members of BMT Al Fath Pesagen, Gunungwungkal, Pati. The results of the research explained that the variables of compliance, assurance, reliability, tangible and empathy did not significantly influence the satisfaction of members of BMT Al Fath. The variables of responsiveness have a positive and significant influence on the satisfaction of BMT Al Fath members. Compliance, assurance, reliability, tangible, empathy and responsiveness together simultaneously and positively affect the satisfaction of members of BMT Al Fath.

\subsection{Consumer Satisfaction}

According to Philip Kotler and Kevin Lane Keller (2007: 177), quoted from the book Marketing Management said that customer satisfaction is a feeling of pleasure or disappointment that someone appears after comparing the product performance that is thought about the expected performance. Consumer satisfaction is the level of consumer 


\section{Vol-2, Issue-2, 2018 (IJEBAR)}

ISSN: 2614-1280, http://www.jurnal.stie-aas/ijebar

feelings after comparing what he receives and his expectations (Tjiptono, 2008). A customer, if he feels satisfied with the value provided by a product or service, it is very likely that he will become a customer for a long time and be loyal to the product or service.

Members in an Islamic financial institution can experience various levels of satisfaction after receiving service from the institution. The level of member satisfaction will be directly proportional to the service received. Maximum satisfaction will generate consumer loyalty not to switch to other financial institutions. Service quality can also be used as a tool to achieve competitive advantage and determine the success and quality of a company.

\subsection{Service Quality}

Service quality is closely related to customer satisfaction. Satisfaction received by customers will foster the urge to establish long-term sustainable cooperation. With this kind of mutual need relationship, the sustainability of the company will be more maintained.

Although service quality and level of satisfaction are two interconnected concepts, both are not something that is truly the same. Many studies prove that service quality is based on long-term cognitive evaluation, while satisfaction is a short-term emotional reaction to certain service experiences.

\subsection{Service Dimensions in an Islamic Perspective}

Islam is a religion that has all the rules in terms of life. In relation to business, Islam has arranged that every person or company must provide services from a service that is run in good quality. Quality services will create a sense of security and peace, so implementing a sense of comfort is created in dealing and cooperating and can give birth to a relationship between the two parties concerned

There are several approaches to the dimensions of service quality, including Parasuraman et al (1998) where there are five dimensions designed to measure service quality based on the difference between the value of expectations and the value of performance perceived by consumers, namely: sharia compliance, responsiveness, reliabillity, assurance, empathy and tangible.

Another approach that can be used is the CARTER approach model of Othman and Owen (2002) in Dani Rohmati and Sunan Fanani (2016), this approach is usually used to measure the satisfaction of Muslim consumers. The development of Islamic organizations has given a dimension in the measurement of service quality that can be used in institutions that make sharia the basis of its organization. The quality of service with CARTER dimensions if described in Islamic concept is as follows:

a. Compliance is the most important dimension in measuring service quality due to sharia compliance which is a manifestation of a Muslim's existence. Compliance is compliance with the rules or laws set by Allah Ta'ala. The ability of a financial institution to apply Sharia principles in its opersional. Does not lend money, but implements a system of profit sharing and trading in transactions (not applying usury). 


\section{Vol-2, Issue-2, 2018 (IJEBAR)}

ISSN: 2614-1280, http://www.jurnal.stie-aas/ijebar

b. Assurance

In providing services to members financial institutions should instill a sense of trust and communication so that members still believe in the products contained in the financial institution. Financial institutions should avoid fraud so that customers/ members will not be disappointed and judge the institution in a negative manner that can be detrimental. Both the bad behavior of business entrepreneurs determine the success and failure of the business run.

\section{c. Reliabillity}

Reliabillity is the ability to provide promised services accurately, quickly and satisfactorily physically and reliably. This means that the services provided must be reliable, responsible and employees should be polite and friendly. Members will feel satisfied if the service received as expected. Providing services that are promised immediately, accurately and satisfactorily is proof of the company's reliability.

\section{d. Tangible}

Tangible (physical ability) is a form of physical appearance including supporting infrastructure, facilities, equipment, employees and other means. Physical ability of the company can be seen from the appearance of employees, waiting room, parking area and so forth. Service within the tangible dimension can be directly seen with the eye directly, so members can directly assess the services provided to it. According to Tjiptono (2008), physical evidence of the services, can be physical buildings, equipment used, employees and means of communication.

e. Empathy (attention) is the ability of the company in giving attention that is individual or personal to the consumer. According Tjiptono (2008), empathy is the ability to make relationships, good communication, personal attention and understand the needs of the customers. Both companies and employees must be able to establish relationships, good communication, personal attention and understanding of the individual needs of members. Empathy relates to the ability of employees to pay attention to members, caring and gentle.

\section{f. Responsiveness}

According Tjiptono (2008), explaining the responsiveness is the desire of employees to help the customers in providing services quickly and responsive. In general responsiveness is an ability to deliver promised services accurately, quickly and satisfactorily physically and reliably. This means that the services provided must be reliable, responsible and employees should be polite and friendly. Members will feel satisfied if the service received as expected.

Responsiveness relates to the willingness of organizational resources to provide assistance to customers and the ability to 
ISSN: 2614-1280, http://www.jurnal.stie-aas/ijebar

service quickly (responsively) and earnestly. Professional organizations are committed to providing the best service, paying attention to expectations and input from customers and responding quickly and accurately.

\subsection{Akad Mudharobah}

In the Islamic finance system there are several contracts between members and financial institutions. The contracts include musyarakah (or also called syirkah) where one variation is mudarabah. In mudharabah syirkah, if there is a profit, the profit is divided according to the profit sharing ratio agreed by both parties. Whereas if the loss, the person with capital (shahib al-mal) will bear the financial loss. The person contributing his services (mudharib) does not bear any financial loss. The form of loss borne by mudharib is the loss of time and effort that he has been mobilizing without getting any reward (Adiwarman, A.Karim. 2016: 78).

Islamic financial institutions have fund collection products that can be used based on their respective principles, namely: Wadiah is a deposit agreement where the items that are deposited can be at any time, where the receiving party can request services for construction and maintenance. And the next product is mudharabah, which is a business contract in which one party provides capital (sahibul mal), while the other party provides expertise (mudharib) with a ratio that is marked and profitable that occurs, the owner of the capital loses it.

In KSPPS BMT Tumang has 10 kinds of deposits. From the more 10 types of savings there are three main savings, namely Mudharabah Savings Al Mutholaqoh, Deposits Mudharabah Futures and Future Mudharabah Deposits.

Mudharabah Al Mutholaqoh deposits are deposits based on the mudharabah almuthlaqah sharia rules, namely mudharib gives confidence to the BMT Tumang to utilize funds that can be used in the form of productive financing. In addition, it can provide benefits to other members in a halal and professional manner. Profit from financing is shared between members and BMTs according to the ratio (profit share) agreed upon at the outset. These deposits can be taken at any time (Mariyana Ricky 2018: 122).

Futures Mudharabah Deposits in principle are almost the same as $\mathrm{Al}$ Mutholaqoh Mudharabah Deposits. Only in Mudharabah Futures Deposits usually there are additional special requirements, among others, determining the minimum deposit limit and taking deposits must be in accordance with the agreement of the time agreement agreed upon at the beginning of the contract.

Future Mudharabah Deposit is savings product in BMT Tumang with mutlaqoh contract principle, mudharabah agreement which does not require certain agreement (unrestricted investment). The deposit is planned specifically for the needs of members in the future (Mariyana Ricky 2018: 122).

\subsection{Hypothesis}

a. H1: Compliance variables have a positive and significant effect on the members' satisfaction of the KSPPS BMT Tumang mudharabah deposit.

b. H2: Assurance variable has positive and significant effect to members' 


\section{Vol-2, Issue-2, 2018 (IJEBAR)}

ISSN: 2614-1280, http://www.jurnal.stie-aas/ijebar

satisfaction of mudharabah of KSPPS BMT Tumang.

c. H3: The variable of reliabillity has a positive and significant effect on the members' satisfaction of mudharabah savings KSPPS BMT Tumang.

d. H4: Tangible variables have positive and significant effect on members' satisfaction of mudharabah of KSPPS BMT Tumang.

e. H5: Variable empathy have positive and significant effect to members satisfaction of mudharabah of KSPPS BMT Tumang.

f. H6: Variable reponsivenes have positive and significant effect on members satisfaction of mudharabah of KSPPS BMT Tumang.

g. H7: Variables of compliance, assurance, reliabillity, tangible, empathy and reponsiveness simultaneously have a positive and significant effect on members satisfaction of mudharabah savings KSPPS BMT Tumang.

\section{Research Methodology}

The populationin this study were members of mudharabah deposit in KSPPS BMT Tumang Selo branch which is 3,800 members, consisting of Mudharabah $\mathrm{Al}$ Mutholaqoh, Mudharabah Futures member and Mudharabah Futures member.

The sample of this research is a member who performs mudharabah deposit in KSPPS BMT Tumang Selo branch either Mudharabah member of $\mathrm{Al}$ Mutholaqoh, Mudharabah Futures member and Mudharabah Future savings member.
So the number of samples in this study will be calculated by the Slovin formula, namely:

$$
\begin{aligned}
& s=\frac{N}{1+N \cdot e^{2}} \quad \text { that is } \\
& s=\frac{3.800}{1+3.800 \times 0,1^{2}}=97,44 \\
& \text { rounded to } 98 \text { samples }
\end{aligned}
$$

Where $\mathrm{s}$ is the number of samples, $\mathrm{N}$ is the number of population with $\mathrm{e}$ is the error rate.

In this study the type of data used is primary data, namely data derived from the main source, namely members of the KSPPS mudharabah deposit BMT Tumang Selo branch as respondents.

The data collection in this study is using questionnaire technique. The questionnaire sheets are equipped with a tiered interval scale. The interval scale itself is used to assess research variables such as compliance, assurance, reliability, tangible, empathy and responsiveness and member satisfaction. This scale is for determining the weight or score about the variables that affect the Service to the Members Satisfaction Deposit Mudharabah KSPPS BMT Tumang Selo branch.

The independent variable used in this study is the measurement of service quality which consists of 6 (six) variables, namely: compliance, assurance, reliability, tangible, empathy and responsiveness.

In the table below will be described independent variables used complete with indicators used.

Table 1. Independen Variable and Resrach Indicator

\begin{tabular}{|c|c|}
\hline Variabel & Indikator \\
\hline
\end{tabular}


Vol-2, Issue-2, 2018 (IJEBAR)

ISSN: 2614-1280, http://www.jurnal.stie-aas/ijebar

\begin{tabular}{|c|c|}
\hline Compliance (X1) & $\begin{array}{l}\text { 1. Operational BMT Tumang Selo Branch in } \\
\text { accordance with Islamic Shari'a. } \\
\text { 2. BMT Tumang Selo Branch implements } \\
\text { the provision of Islamic product service. } \\
\text { 3. The Customer knows about the } \\
\text { Mudharabah savings product which is his } \\
\text { choice. } \\
\text { 4. BMT Tumang Branch. }\end{array}$ \\
\hline Assurance (X2) & $\begin{array}{l}\text { 1. BMT Tumang Selo Branch ensures } \\
\text { customers' security in transactions. } \\
\text { 2. BMT Tumang Branch Selo can store data } \\
\text { correctly and accurately. } \\
\text { 3. Transactions at BMT Tumang Selo } \\
\text { Branch are free from errors. } \\
\text { 4. The staff of BMT Tumang Selo Branch } \\
\text { always carry out their duties correctly and } \\
\text { correctly }\end{array}$ \\
\hline Reliabillity (X3) & $\begin{array}{l}\text { 1. BMT Tumang Selo Branch serves all } \\
\text { customers according to its promise. }\end{array}$ \\
\hline
\end{tabular}

\section{Results and Discussion}

\subsection{Instrument Test Results}

\subsubsection{Validity Test}

Validity test is used to find out whether a questionnaire is valid or not. Questionnaire is said to be valid if the question in the questionnaire is able to reveal something that will be measured in the questionnaire. Validity test is done by comparing the $r$ count and $r$ table values. Data is said to be valid if the value is $r_{\text {count }}>r_{\text {table, }}$, where $r_{\text {table }}$ for degree of freedom $(\mathrm{df})=\mathrm{n}-2$, in this case $n$ is the number of samples. In this study the number ( $\mathrm{n}$ ) is 98 so that the magnitude of df can be calculated 98 - 2 with $\mathrm{df}=96$ and alpha $=0.05$ obtained $\mathrm{r}_{\text {table }}$ of 0.1986 .

The validity test result of the compliance variable $\left(\mathrm{X}^{1}\right)$ is that the 4 item questions $\mathrm{r}$ count each of $0.584 ; 0.758$; $0.750 ; 0,801$; because the 4 item statement has $r_{\text {count }}>r_{\text {table }}(n=98, \alpha=0,05)$, then the 4 item of compliance variable statement $\left(\mathrm{X}^{1}\right)$ valid or valid. So the 4 items statement of variable compliance $\left(\mathrm{X}^{1}\right)$ can be continued with reliability testing.

The validity test result of the assurance variable $\left(\mathrm{X}^{2}\right)$ note that the 4 items of question $\mathrm{r}$ count each of 0.461 ; $0.776 ; 0.799 ; 0,756$; because the 4 item statement has $r_{\text {count }}>r_{\text {table }}(n=98, \alpha=$ $0,05)$, then the 4 item statement of assurance variable $\left(\mathrm{X}^{2}\right)$ is valid or valid. So the 4 items of assurance $\left(X^{2}\right)$ variable statement can be continued with the reliability test.

The validity test result of reliability variable $\left(\mathrm{X}^{3}\right)$ note that the 4 items question $r$ count each of equal to $0.839 ; 0,696$; $0.820 ; 0,772$; because the four statement items have $r$ count $>r$ table $(n=98, \alpha=$ 0.05), then all four items of variable 
statement riliabillity $\left(\mathrm{X}^{3}\right)$ are valid or valid. So the 4 item statement of riliabillity variable $\left(\mathrm{X}^{3}\right)$ can be continued its reliability test.

The validity test result of reliability variable (X4) is known that the 4 items of question $\mathrm{r}$ count is 0,514 each; 0.750 ; $0.795 ; 0,643$; because the 4 statement items have $r$ count $>r$ table $(n=98, \alpha=$ $0.05)$, then the 4 items statement tangible variable $\left(\mathrm{X}^{4}\right)$ is valid or valid. So the $4^{\text {th }}$ item.

The result of validity test of fourhy variable $\left(\mathrm{X}^{5}\right)$ is known that the 4 items of question $\mathrm{r}$ counted each of $0.866 ; 0.767$; $0.764 ; 0.726$; This is because the 4 statement items have $r_{\text {count }}>r_{\text {able }}(n=98$, $\alpha=0.05$ ), then the four items of the empathy variable statement $\left(\mathrm{X}^{5}\right)$ are valid or valid. So the 4 item statement of empathy variable $\left(\mathrm{X}^{5}\right)$ can be continued its reliability test.

The result of the validity test of responsiveness variable $\left(\mathrm{X}^{6}\right)$ is known that the 4 items of question $r$ count is 0,796 ; $0.811 ; 0.853 ; 0.712$; because the four statement items have $\mathrm{r}$ count $>\mathrm{r}$ table $(\mathrm{n}=$ 98, $\alpha=0.05)$, then the 4 items statement variable responsivenes $\left(\mathrm{X}^{6}\right)$ are valid or valid. So the 4 items statement of responsiveness variable $\left(X^{6}\right)$ can be continued its reliability test.

Test results of validity of satisfaction variable $(\mathrm{Y})$ note that the 6 items of question $r$ count respectively equal to 0.749 ; $0.831 ; 0.795 ; 0,782 ; 0,783 ; 0.834$; because the 6 statement items have $\mathrm{r}$ count $>\mathrm{r}$ table $(\mathrm{n}=98, \alpha=0.05)$, then the 6 satisfaction statement $(\mathrm{Y})$ variable items are valid or valid. So the 6 items of the variable statement of satisfaction (Y) can be continued the reliability test.

\subsubsection{Reliability Test}

Table 3. Relliability Test Result

\begin{tabular}{|c|l|c|c|}
\hline & \multicolumn{1}{|c|}{ Variabel } & Jumlah pertanyaan & Cronbach alpha \\
\hline No. & Complaince (X1) & 4 items & 0,687 \\
\hline 2 & Assurance (X2) & 4 items & 0,647 \\
\hline 3 & Reliabillity (X3 ) & 4 items & 0,774 \\
\hline 4 & Tangible (X4) & 4 items & 0,617 \\
\hline 5 & Empathy (X5) & 4 items & 0,786 \\
\hline 6 & Responsivenes (X6) & 4 items & 0,799 \\
\hline 7 & Kepuasan ( Y ) & 6 items & 0,883 \\
\hline
\end{tabular}

Source: research results processed, 2018

Based on the results of reliability test above, indicating the instrument for each research variable is reliable or reliable, because cronbach alpha> 0.60 and this proves that the internal consistency measurement used in this study can be considered good.
4.2 Hypothesis
Test Results and Discussion

4.2.1 Multiple Linier Regression 
International Journal of Economics, Business and Accounting Research (IJEBAR)

Peer Reviewed - International Journal

Vol-2, Issue-2, 2018 (IJEBAR)

ISSN: 2614-1280, http://www.jurnal.stie-aas/ijebar

The multiple model in this study was to examine the effect of independent variables compliance (X1), assurance (X2), reliability (X3), tangible (X4), empathy (X5), responsiveness (X6) on the dependent variable member satisfaction (Y). The results of multiple regression analysis statistical tests can be seen in the following table:

Table 4. Summary of Hypothesis Test Results

\begin{tabular}{|c|c|c|c|c|}
\hline Variable & $\mathrm{b}$ & $\mathrm{t}_{\text {hitung }}$ & Sig & Conclusion \\
\hline Constans & 1,572 & & & \\
\hline x.1_Compliances & 0,125 & 1,009 & 0,316 & Not significant \\
\hline x.2_Assurance & 0,016 & 0,182 & 0,856 & Not significant \\
\hline x.3_Reliabillity & $-0,052$ & $-0,400$ & 0,690 & Significant influence \\
\hline x.4_Tangible & 0,051 & 0,568 & 0,572 & Significant influence \\
\hline x.5_Emphaty & 0,498 & 3,699 & 0,000 & Not significant \\
\hline x.6_Emphaty & 0,771 & 6,595 & 0,000 & Not significant \\
\hline \multicolumn{2}{|l|}{$\mathrm{F}_{\text {count }}$} & 30,786 & 0,000 & Significant influence \\
\hline \multicolumn{2}{|l|}{ Adjusted R Square } & \multicolumn{3}{|c|}{0,648} \\
\hline
\end{tabular}

Source: processed research results, 2018

Based on the table above, the results of the equation are as follows:

$$
\begin{aligned}
& \mathrm{Y}=\beta 0+\beta 1 X_{1}+\beta_{2} X_{2}+\beta 3 X_{3}+ \\
& \beta_{4} \mathrm{X}_{4}+\beta 5 \mathrm{X}_{5}+\beta_{6} \mathrm{X}_{6}+\mathrm{e}
\end{aligned}
$$

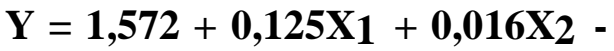

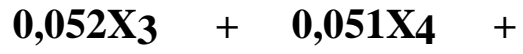

$$
\begin{aligned}
& 0,498 X_{5}+0,771 X_{6}+e
\end{aligned}
$$

Based on the results of the multiple linear regression equation above, it can be seen that the five independent variables namely compliance, assurance, tangible, empathy and responsiveness have a positive effect on member satisfaction, while one independent variable namely reliabillity has a negative effect on member satisfaction.

\subsection{2 $\mathrm{T}$ test (Partial)}

$\mathrm{T}$ test is done to test the research hypothesis and determine the effect of each independent variable on the dependent variable.

Based on table 4 about the results of multiple linear regression analysis, conclusions can be drawn as follows:

a. Test the effect of compliance variables on the members' satisfaction of the KSPPS BMT Tumang mudharabah deposit.

The compliance variable has a $t_{\text {count }}$ of $1.009<\mathrm{t}_{\text {table }}$ of 1.986 and a significance value of $0.316>0.05$, so that $H_{o}$ is accepted meaning there is no significant influence between compliance with member satisfaction.

Compliance is a form of compliance with the KSPPS BMT Tumang Selo branch against the rules and laws of 


\section{Vol-2, Issue-2, 2018 (IJEBAR)}

ISSN: 2614-1280, http://www.jurnal.stie-aas/ijebar

Islamic law in carrying out its operations. This principle of compliance is intended to increase the satisfaction of KSPPS BMT Tumang members. Providing Islamic service products, an explanation of the contract that will be chosen by members and the application of profit sharing has been implemented in this institution.

The results of this study are in line with research conducted by Zuanita Amalia Sulistiyani (2017), which states that the compliance variable does not significantly influence the satisfaction of members of BMT Al Fath Pesagan. On the contrary, the results of this study are contrary to the results of research conducted by Kharismarisa Nurhayati, Real Nugraha (2015), which states that compliance variables significantly influence customer satisfaction KJKS BMT Fastabiq Pati.

If we look at the questionnaire distribution that has been filled in by the respondent, the factors that cause compliance variables have no significant effect on the level of satisfaction of members of the mudharabah deposit in KSPPS BMT Tumang Selo branch is the low level of education and the lack of member knowledge about Islamic economics.

b. Test of the assurance variables effect on the members'satisfaction of the KSPPS BMT Tumang mudharabah deposit

The assurance variable has a tcount of $0.182<\mathrm{t}_{\text {table }}$ of 1.986 and a significance value of $0.856>0.05$, so that $\mathrm{Ho}$ is accepted meaning there is no significant effect between assurance and member satisfaction.
This research is the same as the results of research conducted by Dani Rohmati, Sunan Fanani (2016) which states that assurance does not significantly influence the satisfaction of employee cooperative members of the Islamic Financial Services Unit of the Palapa Nusantara Foundation with a significance value of $0.567>0.05$. Instead the results of this study are contrary to the results of research conducted by Kharismarisa Nurhayati, Real Nugraha (2015), which states that the assurance variable significantly influences customer satisfaction KJKS BMT Fastabiq Pati with a significance value of 0.016 $<0.05$.

When viewed from the questionnaire distribution that has been filled in by the respondents, the factors that cause the assurance variable to have no significant effect on the members' satisfaction level of mudharabah deposits in KSPPS BMT Tumang Selo branch is a security guarantee that has not been fully fulfilled. So the level of members' satisfaction of the KSPPS BMT Tumang Selo branch for this funding has not been significant.

c. Test the effect of reliabillity variables on members' satisfaction of the KSPPS BMT Tumang mudharabah deposit

The reliabillity variable has a $t_{\text {count }}$ of $0.400<\mathrm{t}_{\text {table }}$ of 1.986 and a significance value of $0.690>0.05$, so $H_{o}$ is accepted which means that there is no significant influence between reliabillity and member satisfaction.

Reliabillity is the ability of KSPPS BMT Tumang Selo branch to provide promised services immediately, accurately and satisfactorily. The reliability referred 


\section{Vol-2, Issue-2, 2018 (IJEBAR)}

ISSN: 2614-1280, http://www.jurnal.stie-aas/ijebar

to in this study is that employees can immediately serve members in accordance with expectations, do not discriminate between existing members and can provide information about existing products to members accurately.

The results of this study are in accordance with previous research conducted by Zuanita Amalia Sulistiyani (2017), which states that reliabillity variables have no significant effect on the satisfaction of members of BMT Al Fath Pesagan with a significance value of $0.082>0.05$. Instead the results of this study contradict the results of research conducted by Dani Rohmati, Sunan Fanani (2016) which states that reliabillity has a significant effect on the satisfaction of employee cooperative members of the Islamic Financial Services Unit of Palapa Nusantara Foundation with a significance value of $0.002<0.05$.

From the questionnaire distribution that has been filled in by respondents, factors that cause reliabillity variables do not have a significant effect on the level of satisfaction of members of mudharabah deposits in KSPPS BMT Tumang Selo branch, among others, not all. employees provide accurate explanations about Islamic products in KSPPS BMT Tumang. This affects the level of members' satisfaction because they do not fully understand the products owned by KSPPS BMT Tumang.

d. Test of tangible effect variables on the satisfaction of members of KSPPS BMT Tumang mudharabah savings

Tangible variable has tcount of 0.568 $<\mathrm{t}_{\text {table }}$ of 1.986 and significance value of $0.572>0.05$, so that $H_{o}$ is accepted meaning there is no significant influence between tangible and member satisfaction. Physical evidence or tangible facilities and infrastructure facilities owned by KSPPS BMT Tumang Selo branch to support transaction activities and member convenience.

The physical evidence referred to in this study is the added value of services obtained by members in real form, including the location of offices, technological facilities, media information and other facilities.

The results of this study are in line with previous research conducted by Kharismarisa Nurhayati, Real Nugraha (2015), which states that tangible variables have no significant effect on customer satisfaction KJKS BMT Fastabiq Pati with a significance value of $0.931>0.05$. This result is also in line with the research of Zuanita Amalia Sulistiyani (2017), which states that reliabillity variables have no significant effect on the satisfaction of members of BMT Al Fath Pesagan with a significance value of $0.137>0.05$.

When viewed from the questionnaire distribution that has been filled in by respondents, the factors that cause the tangible variable do not have a significant effect on the level of satisfaction of members of mudharabah deposits in KSPPS BMT Tumang Selo branch, among others, not all services use modern equipment, buildings and parking areas that are still one area with other buildings, as well as the provision of other supporting facilities that are still incomplete.

e. Test of variable empathy effect on the satisfaction of members of the KSPPS BMT Tumang mudharabah deposit 


\section{Vol-2, Issue-2, 2018 (IJEBAR)}

ISSN: 2614-1280, http://www.jurnal.stie-aas/ijebar

Variable empathy has a tcount of $3.699>\mathrm{t}_{\text {table }}$ of 1.986 and a significance value of $0.000<0.05$, so that $\mathrm{H}_{\mathrm{o}}$ is rejected meaning there is a significant influence between empathy and member satisfaction.

Empathy is a form of service of KSPPS employees BMT Tumang Selo branch that is sincere and individual to fulfill the wishes of members. The meaning of empathy in this study BMT employees can provide services with attentive, friendly and polite and caring attitude towards members and the surrounding community.

The results of this study are in accordance with the research conducted by Kharismarisa Nurhayati, Real Nugraha (2015), which states that the empathy variable significantly affects customer satisfaction of KJKS BMT Fastabiq Pati with a significance value of $0.007<0.05$. Instead the results of this study contradict the research of Zuanita Amalia Sulistiyani (2017), which states that the empathy variable does not significantly influence the satisfaction of members of BMT Al Fath Pesagan with a significance value of $0.227>0.05$.

When viewed from the distribution of questionnaires that have been filled in by respondents, there are several things that strongly support that empathy variables have a positive and significant effect, including employee friendliness and courtesy when providing services, attention and patience in serving transactions, sympathy for member problems and concern for the social activities of the surrounding community. f. Test of variable responsivenes effcet on the satisfaction of members of the KSPPS BMT Tumang mudharabah deposit

The variable responsivenes has tcount of $6.595>t_{\text {table }}$ of 1.986 and a significance value of $0.000<0.05$, so that $\mathrm{H}_{\mathrm{o}}$ is rejected meaning that there is a significant influence between responsivenes and member satisfaction.

Responsivenes (capture power) is a form of service provided by KSPPS BMT Tumang Selo branch in the form of fast and appropriate service to members and can provide clear information. Responsivenes in this study relate to the fast, precise and efficiency of BMT in serving members, the ability to provide solutions and answers to member problems, accuracy in rush hour and the response to the needs of BMT members.

The results of this study are in accordance with research conducted by Kharismarisa Nurhayati, Real Nugraha (2015), which states that responsivenes variables significantly influence customer satisfaction KJKS BMT Fastabiq Pati with a significance value of $0.018<0.05$. This research also strengthens the research of Zuanita Amalia Sulistiyani (2017), which states that responsiveness variables have a significant positive effect on the satisfaction of members of BMT Al Fath Pesagan with a significance value of 0.004 $<0.05$.

There are several things that strongly support that responsiveness variables have a positive and significant effect on member satisfaction, including BMT having sufficient knowledge to answer member questions and problems, prompt and 


\section{Vol-2, Issue-2, 2018 (IJEBAR)}

ISSN: 2614-1280, http://www.jurnal.stie-aas/ijebar

accurate services and responsiveness to members' needs.

\subsubsection{F Test (Simultaneous)}

F statistic test basically shows whether all independent variables included in the model have a simultaneous effect on the dependent variable (Ghozali, 2006: 62).

Based on table 4 above with a significance of $5 \%$ obtained $\mathrm{F}$ table of 2.19 because $\mathrm{F}_{\text {count }}=30.778>\mathrm{F}_{\text {table }}=2.19$ and a significant value of $\mathrm{F}$ of $0.000<0.05$, compliance, assurance, reliabillity, tangible, empathy and responsivenes simultaneously effect on member satisfaction.

\subsubsection{Model Accuracy Test $\left(\mathbf{R}^{2}\right)$}

Based on the output model output summary in table 4 above the amount of adjusted $\mathrm{R}^{2}$ (coefficient of determination that has been adjusted) is 0.648 or $64.8 \%$. This value shows that $64.8 \%$ dependent variable (member satisfaction) can be explained by independent variables which include compliance, assurance, reliabillity, tangible, empathy and responsivenes, the remaining 0.352 or $35.2 \%$ is explained by other variables outside the variables used in the study this.

\section{Conclusions And Suggestions}

\subsection{Conclusion}

a. Based on the partial test, the variables compliance $\left(\mathrm{X}^{1}\right)$, assurance $\left(\mathrm{X}^{2}\right)$, reliabillity $\left(\mathrm{X}^{3}\right)$, tangible $\left(\mathrm{X}^{4}\right)$ parsiil did not significantly influence the members' satisfaction of the KSPPS mudharabah deposit BMT Tumang Selo branch.

b. Based on the partial test of empathy variable (X5), responsivenes (X6) have a significant effect on the members' satisfaction of the KSPPS mudharabah deposit BMT Tumang Selo branch.

c. Compliance $\left(\mathrm{X}^{1}\right)$, assurance $\left(\mathrm{X}^{2}\right)$, reliabillity $\left(\mathrm{X}^{3}\right)$, tangible $\left(\mathrm{X}^{4}\right)$, empathy $\left(X^{5}\right)$ and responsivenes $\left(X^{6}\right)$ simultaneously have a significant effect on the members' satisfaction of the mudharabah deposit KSPPS BMT Tumang Selo Branch. These results support the research conducted by Zuanita Amalia Sulistiyani (2017).

d. $64.8 \%$ dependent variable (member satisfaction) can be explained by independent variables including compliance, assurance, reliabillity, tangible, empathy and responsivenes, the remaining 0.352 or $35.2 \%$ is explained by other variables outside the variables used in this study.

\subsection{Suggestions}

a. Factors that cause compliance variables have no significant effect on the members' satisfaction level of mudharabah deposits in KSPPS BMT Tumang Selo branch is the low level of education and the lack of member knowledge about Islamic economics. For this reason BMT Tumang must pay attention to the dissemination of information to the public. Socialization must be the main program of this institution, because BMT is not only a financial institution that is only profit oriented, but there is a da'wah media that must be considered.

b. KSPPS BMT Tumang Selo branch must pay attention to and improve the service system and maintain 
ISSN: 2614-1280, http://www.jurnal.stie-aas/ijebar

reputation so that members have the confidence and security (assurance) to keep their funds in KSPPS BMT Tumang.

c. KSPPS BMT employees in the Selo branch must be more maximal in providing understanding and convenience to the products needed by members. Employees want to be able to immediately serve members in accordance with expectations, do not discriminate between existing members and can provide information about existing products to members accurately.

b. Subsequent research should use variables other than the variables used in this study compliance, assurance, reliabillity, tangible, empathy and responsivenes. The addition of related variables that can be used include: competences, access, communication, management, credibility or security.

\section{Thank-You Note}

This research was carried out supported by the Amaliyah Ilmi Foundation as the organizer of STIE AAS Surakarta. We thank all the lecturers at STIE AAS Surakarta who have shared insights and knowledge that were very helpful in the implementation of this research.

We also express our gratitude to the entire academic community of STIE-AAS Surakarta for supporting the completion of this research.

\section{Reference}

Adiwarman, A.Karim. 2016. Bank Islam: Analisis Fiqih dan Keuangan.
Jakarta: PT. Raja Grafindo

Persada.

Dani Rohmati, Sunan Fanani. 2016. "Implemtasi kualitas pelayanan pendekatan CARTER dan pengaruhnya terhadap kepuasan UJKS koperasi karyawan". AlTijary: Jurnal Ekonomi dan Bisnis Islam. (2016):203-218.

Depag .RI. 2005. Al-Quran dan Terjemahannya. Bandung: Sygma.

Ghozali, Imam. 2006. Aplikasi Analisis Multivariate dengan Program SPSS, Semarang: Undip.

J. Supranto. 2008. Statistik: Teori dan Aplikas. Jakarta: Erlangga.

Kharismarisa Nurhayati, Nyata Nugraha. 2015. "Analisis Pengaruh Kualitas Pelayanan Terhadap Kepuasan Anggota KSPPS BMT Fastabiq Pati”. Al-Tijary: Jurnal Ekonomi dan Bisnis Islam. (2015):67-76.

KJKS BMT Tumang. 2017. Buku Laporan: Memperkuat Basis Koperasi Syariah. Boyolali: BMT Tumang.

Kotler, Kevin. 2007. Manajemen Pemasaran. Jakarta : Erlangga.

Mariyana Ricky. 2018. Inspirasi Bumbung Bambu: Kisah Juang Adib Zuhari Membangun BMT Tumang. Solo: PT. Aksara Solopos. 
International Journal of Economics, Business and Accounting Research (IJEBAR)

Peer Reviewed - International Journal

Vol-2, Issue-2, 2018 (IJEBAR)

ISSN: 2614-1280, http://www.jurnal.stie-aas/ijebar

Ridwan.2005. Belajar Mudah Penelitian

Untuk Guru, Karyawan dan

Peneliti Pemula. Bandung:

Alfabeta.

Sugiyono. 2015. Metode Penelitian

Kuantitatif , Kualitatif dan $R \& D$.

Bandung: CV Alfabeta.

Tjiptono, Fandy. 2008. Strategi

Pemasaran. Yogyakarta: Andi Offset.
Wijaya, Tony. 2011. Manajemen Kualitas Jasa. Jakarta: Indeks.

Zuanita Amalia Sulistiyani. 2017. "Analisa kualitas pelayanan terhadap kepuasan anggota dengan dimansi CARTER". AlTijary: Jurnal Ekonomi dan Bisnis Islam. (2018). 